\title{
KEMAMPUAN PEDAGOGIK GURU
}

\author{
Wahyu Bagja Sulfemi, S.Pd., M.Pd. \\ Dosen Tetap dan Ketua Prodi Administrasi Pendidkan \\ STKIP Muhammadiyah Bogor \\ wahyubagja@gmail.com
}

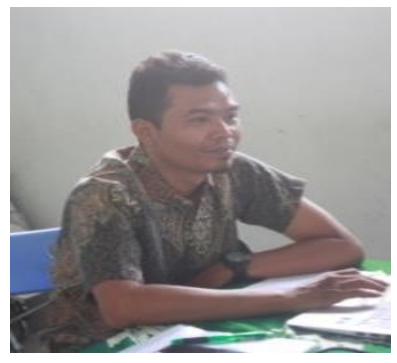

\begin{abstract}
Abstrak
Peranan guru sangat menentukan dalam usaha peningkatan mutu pendidikan formal. Untuk itu guru sebagai agen pembelajaran dituntut untuk mampu menyelenggarakan proses pembelajaran dengan sebaik-baiknya, dalam kerangka pembangunan pendidikan. Guru mempunyai fungsi dan peran yang sangat strategis dalam pembangunan bidang pendidikan, dan oleh karena itu perlu dikembangkan sebagai profesi yang bermartabat. Undang-Undang No. 14 tahun 2005 tentang Guru dan Dosen Pasal 4 menegaskan bahwa guru sebagai agen pembelajaran berfungsi untuk meningkatkan mutu pendidikan nasional. Untuk dapat melaksanakan fungsinya dengan baik, guru wajib untuk memiliki syarat tertentu, salah satu di antaranya adalah kompetensi. Kompetensi guru merupakan seperangkat penguasaan kemampuan yang harus ada dalam diri guru agar dapat mewujudkan kinerja secara tepat dan efektif. Sedangkan guru yang profesional adalah guru yang memiliki kemampuan dan keahlian khusus dalam bidang keguruan sehingga mampu melaksanakan tugas dan fungsinya sebagai guru dengan kemampuan maksimal. Guru merupakan orang yang sangat berpengaruh dalam proses belajar mengajar. Sudah selayaknya seorang guru itu diberikan kesejahteraan berupa sertifikasi. Dapat dipahami bahwa sertifikasi adalah proses pemberian sertifikat pendidik kepada guru yang telah memenuhi persyaratan tertentu, yaitu memiliki kualifikasi akademik, kompetensi, sehat jasmani dan rohani, serta memiliki kemampuan untuk mewujudkan tujuan pendidikan nasional yang disertai dengan peningkatan kesejahteraan yang layak.
\end{abstract}

\section{A. Pendahuluan}

Tentang kompetensi ini ada beberapa rumusan atau pengertian yang perlu dicermati yaitu Kompetensi (competence), menurut Hall dan Jones yaitu pernyataan yang menggambarkan penampilan suatu kemampuan tertentu secara bulat yang merupakan perbaduan antara pengetahuan dan kemampuan yang dapat diamati dan diukur. Selanjutnya Richards menyebutkan bahwa istilah kompetensi mengacu kepada perilaku yang dapat diamati, yang diperlukan untuk menuntaskan kegiatan sehari-hari. (Muslich, $2007: 15)$ 
Dalam UU guru dan dosen, BAB I (Ketentuan Umum) pasal 1 ayat 10 bahwa pengertian kompetensi adalah seperangkat pengetahuan, keterampilan, dan perilaku yang harus dimiliki, dihayati, dan dikuasai oleh guru atau dosen dalam melaksanakan tugas keprofesionalan(Undang-Undang Guru dan Dosen, 2011 : 4). Kompetensi merupakan kemampuan dan kewanangan guru dalam melaksanakan profesi keguruannya. Bahwa kompetensi mengacu pada kemampuan melaksanakan sesuatu yang diperoleh melalui pendidikan, kompetensi merujuk kepada performance dan perbuatan yang rasional untuk memenuhi verifikasi tertentu di dalam pelaksanaan tugas-tugas kependidikan(Hawi, 2010 : 4) Guru profesional harus memiliki 4 (empat) kompetensi yaitu kompetensi pedagogis, kognitif, personality, dan social. Oleh karena itu, selain terampil mengajar, seorang guru juga memiliki pengetahuan yang luas, bijak dan dapat bersosialisasi dengan baik. Sebagaimana disebutkan dalam UU No. 14 tahun 2005 tentang guru dan dosen, maka guru harus memiliki

1. Memiliki bakat, minat, panggilan jiwa, dan idealisme.

2. Memiliki kualifikasi pendidikan dan latar belakang pendidikan yang sesuai dengan bidang tugasnya.

3. Memiliki kompetensi yang diperlukan sesuai dengan bidang tugasnya.

4. Mematuhi kode etik profesi.

5. Memiliki hak dan kewajiban dalam melaksanakan tugas.

6. Memperoleh penghasilan yang ditentukan sesuai dengan prestasi kerjanya.

7. Memiliki kesempatan untuk mengembangkan profesinya secara berkelanjutan.

8. Memperoleh perlindungan hukum dalam melaksanakan tugas profesionalnya, dan

9. Memiliki organisasi profesi yang berbadan hukum.

\section{B. Pengertian Kompetensi}

Kompetensi diartikan sebagai suatu hal yang menggambarkan kualifikasi atau kemampuan seseorang, baik yang kualitatif maupun kuantitatif. Kompetensi didefinisikan sebagai kewenangan (memutuskan sesuatu). Ada juga yang mengatakan bahwa "kompetensi atau secara umum diartikan sebagai kemampuan dapat bersifat mental maupun fisik."

esuai dengan Undang-Undang Peraturan Pemerintah. No14 tahun 2005 pada pasal 8 mengatakan tentang kompetensi seorang guru. Ada 4 kompetensi dasar yang harus dimiliki oleh seorang guru, antara lain: kompetensi kepribadian, kompetensi pedagogik, kompetensi professional, dan kompetensi sosial. (Wahyudi, 2012 :17-18) 
Dan dalam UU guru dan dosen dalam BAB II (kompetensi dan sertifikasi) pasal 2 "guru wajib memilki kualifikasi akademik, kompetensi, sertifikasi pendidik, sehat jasmani dan rohani, serta memiliki kemampuan untuk mewujudkan tujuan pendidikan nasional. Dan dijelaskan dalam pasal 3 ayat 2 kompetensi guru sebagai mana yang dimaksud meliputi kompetensi pedagogik, kompetensi kepribadian, kompetensi sosial, dan kompetensi professional yang diperoleh melalui pendidikan profesi.(Undang-Undang Guru dan Dosen, 2011 : 65).Dalam penjabaran lain ke-4 kompetensi guru di atas dijabarkan sebagai berikut:

1. Kompetensi Pedagogik

Kompetensi pedagogik merupakan kemampuan dalam mengelola pembelajaran peserta didik, yang meliputi: a) pemahaman peserta didik, b) perancang dan pelaksanaan pembelajaran, c) evaluasi pembelajaran dan, d) pengembangan peserta didik untuk mengaktualisasi berbagai potensi yang dimilikinya.Kompetensi pedagogik yaitu kemampuan seorang guru dalam mengelola proses pembelajaran peserta didik. Selain itu kemampuan pedagogik juga ditunjukkan dalam membantu, membimbing dan memimpin peserta didik. (Wahyudi, $2012: 22$ )

Berdasarkan pengertian seperti tersebut di atas maka yang dimaksud dengan pedagogik adalah ilmu tentang pendidikan anak yang ruang lingkupnya terbatas pada interaksi edukatif antara pendidik dengan siswa. Dapat pula diartikankompetensi pedagaogik adalah sejumlah kemampuan guru yang berkaitan dengan ilmu dan seni mengajar siswa.

Dengan Demikian, kompetensi pedagogik maka guru mempunyai kemampuankemampuan sebagai berikut

1) Mengaktualisasikan landasan mengajar,

2) Pemahaman terhadap peserta didik,

3) Menguasai ilmu mengajar (didaktik metodik),

4) Menguasai teori motivasi,

5) Mengenali lingkungan masyarakat,

6) Menguasai penyusunan kurikulum,

7) Menguasai teknik penyusunan RPP,

8) Menguasai pengetahuan evaluasi pembelajaran, dan lain-lain. (Mulyasa, $2007: 75$ )

Dalam UU guru dan dosen, kompetensi pedagogik sebagaimana yang dimaksud pada ayat 2 merupakan kemampuan guru dalam pengelolaan pembelajaran peserta didik yang sekurang-kurangnya meliputi:

1) Pemahaman wawasan atau landasan kependidikan, 
2) Pemahaman terhadap peserta didik,

3) Pengembangan kurikulum atau silabus,

4) Perancangan pembelajaran,

5) Pelaksanaan pembelajaran yang mendidik dan dialogis,

6) Pemanfaatan teknologi pembelajaran,

7) Evaluasi hasil belajar, dan

8) Pengembangan peserta didik untuk mengaktualisasikan berbagai potensi yang di milikinya. (Undang-Undang Guru dan Dosen, 2011 : 66)

Menurut Permendiknas nomor 16 tahun 2007 pedagogik guru mata pelajaran terdiri atas 37 buah kompetensi yang di rangkum dalam 10 kompetensi inti seperti disajikan berikut;

1) Menguasai peserta didik dari aspek fisik, moral, spiritual, sosial, kultural, emosional, dan intelektual.

2) Menguasai teori belajar dan prinsip-rinsip pembelajaran yang mendidik.

3) Mengembangkan kurikulum yang terkait dengan mata pelajaran yang diampu.

4) Menyelenggarakan pembelajaran yang mendidik.

5) Memanfaatkan teknologi informasi dan komunikasi untuk kepentingan pembelajaran.

6) Memfasilitasi pengembangan potensi peserta didik untuk mengaktualisasikan berbagai pontensi yang dimiliki.

7) Berkomunikasi secara efektif, empatik, dan santun dengan peserta didik.

8) Menyelenggarakan penilaian dan evaluasi proses dan hasil belajar.

9) Memanfaatkan hasil penilaian dan evaluasi untuk kepentingan pembelajaran.

10) Melakukan tindakan reflektif untuk peningkatan kualitas pembelajaran. (Wahyudi, $2012: 23)$

Jadi, dari keseluruhan pengertian tadi dapat kami simpulkan bahwa kompetensi pedagogik adalah cara guru dalam mengajar dan mengatur sistem pembelajaran di kelas dengan menjalin interaksi yang baik terhadap peserta didik.

2. Kompetensi Kepribadian

Kompetensi kepribadian adalah kompetensi yang berkaitan dengan perilaku pribadi guru itu sendiri yang kelak harus memiliki nilai-nilai luhur sehingga terpancar dalam perilaku sehari-hari.(Roqib dan Nurfuadi, 2009 :122). Menurut Hamzah B.Uno (2008 : 69) kompetensi Personal, artinya sikap kepribadian yang mantap sehingga mampu menjadi sumber intensifikasi bagi subjek. Dalam hal ini berarti memiliki kepribadian 
yang pantas diteladani, mampu melaksanakan kepemimpinan seperti yang dikemukakan Ki Hajar Dewantara, yaitu “Ing Ngarsa Sung Tulada, Ing Madya Mangun Karsa. Tut Wuri Handayani”. Dengan kompetensi kepribadian maka guru akan menjadi contoh dan teladan, serta membangkitkan motivasi belajar siswa. Oleh karena itu, seorang guru dituntut melalui sikap dan perbuatan menjadikan dirinya sebagai panutan dan ikutan orang-orang yang dipimpinnya.

Merupakan penguasaan kepribadian yang mantap, stabil, dewasa, arif dan berwibawa, menjadi teladan bagi peserta didik dan berakhlak mulia. Selain itu, seorang guru harus mampu:

1) Bertindak sesuai dengan norma agama, hukum, sosial, dan kebudayaan nasional Indonesia.

2) Menampilkan diri sebagai pribadi yang jujur, berakhlak mulia, dan teladan bagi peserta didik dan masyarakat.

3) Menampilkan diri sebagai pribadi yang mantap, stabil, dewasa, arif, dan berwibawa.

4) Menunjukkan etos kerja, tanggung jawab yang tinggi serta bangga menjadi guru, dan rasa percaya diri.

5) Menunjang tinggi kode etik profesi guru. (Wahyudi, $2012: 19$ )

Menurut Djam'an (2007: 38) kompetensi kepribadian yang perlu dimiliki guru antara lain sebagai berikut:

1) Guru sebagai manusia ciptaan Tuhan Yang Maha Esa berkewajiban untuk meningkatkan iman dan ketakwaannya kepada Tuhan, sejalan dengan agama dan kepercayaan yang dianutnya.

2) Guru memiliki kelebihan dibandingkan yang lain.

3) Guru perlu untuk mengembangkan sikap tenggang rasa dan toleransi dalam menyikapi perbedaan yang ditemuinya dalam berinteraksi dengan peserta didik maupun masyarakat.

4) Guru diharapkan dapat menjadi fasilitator dalam menumbuhkembangkan budaya berpikir kritis di masyarakat, saling menerima dalam perbedaan pendapat dan bersikap demokratis dalam menyampaikan dan menerima gagasan-gagasan mengenai permasalahan yang ada di sekitarnya sehingga guru menjadi terbuka dan tidak menutup diri dari hal-hal yang berada di luar dirinya.

5) Guru diharapkan dapat sabar dalam arti tekun dan ulet melaksaakan proses pendidikan tidak langsung dapat dirasakan saat itu tetapi membutuhkan proses yang panjang. 
6) Guru mampu mengembangkan dirinya sesuai dengan pembaharuan, baik dalam bidang profesinya maupun dalam spesialisasinya.

7) Guru mampu menghayati tujuan-tujuan pendidikan baik secara nasional, kelembagaan, kurikuler sampai tujuan mata pelajaran yang diberikannya.

8) Hubungan manusiawi yaitu kemampuan guru untuk dapat berhubungan dengan orang lain atas dasar saling menghormati antara satu dengan yang lainnya.

9) Pemahaman diri, yaitu kemampuan untuk memahami berbagai aspek dirinya baik yang positif maupun yang negatif.

10) Guru mampu melakukan perubahan-perubahan dalam mengembangkan profesinya sebagai inovator dan kreator.

Jadi, kompetensi kepribadian secara ringkas bagi seorang guru ialah sikap dan tingkah laku yang baik, patut untuk diteladani dan menjadi cerminan untuk peserta didik, mampu mengembang potensi dalam diri, serta yang paling utama bagi seorang guru yang berkepribadian yaitu bertaqwa kepada Tuhan Yang Maha Esa, mematuhi norma agama, hukum dan sosial yang berlaku.

\section{Kompetensi Sosial}

Dimaksud dengan kompetensi sosial di dalam Peraturan Pemerintah Nomor 19 tahun 2005 , pada pasal 28 , ayat 3 , ialah kemampuan pendidik sebagai bagian dari masyarakat untuk berkomunikasi dan bergaul secara efektif dengan peserta didik, sesama pendidik, tenaga kependidikan, orang tua/wali peserta didik dan masyarakat sekitar.

Kompetensi sosial merupakan kemampuan berkomunikasi secara efektif dengan peserta didik, sesama pendidik/tenaga kependidikan lain, orang tua/wali peserta didik dan masyarakat sekitar. (Wahyudi, 2012 : 25) Sedangkan menurut Hamzah B. Uno (2008 : 69) kompetensi sosial artinya guru harus mampu menunjukkan dan berinteraksi sosial, baik dengan murid-muridnya maupun dengan sesama guru dan kepala sekolah, bahkan dengan masyarakat luas.

Guru profesional hendaknya mampu memikul dan melaksanakan tanggung jawab sebagai guru kepada siswa, orang tua, masyarakat, bangsa, negara, dan agamanya. Tanggung jawab pribadi yang mandiri yang mampu memahami dirinya, mengelola dirinya, mengendalikan dirinya, dan menghargai serta mengembangkan dirinya. Tanggung jawab sosial diwujudkan melalui kompetensi guru dalam memahami dirinya sebagai bagian yang tak terpisahkan dari lingkungan sosial serta memiliki kemampuan berinteraksi sosial. Tanggung jawab intelektual diwujudkan melalui penguasaan berbagai perangkat pengetahuan dan keterampilan yang diperlukan untuk menunjang 
tugas-tugasnya. Tanggung jawab spiritual dan moral diwujudkan melalui penampilan guru sebagai makhluk beragama yang perilakunya senantiasa tidak menyimpang dari norma agama dan norma moral.

Dalam pengertian lain, terdapat kriteria lain kompetensi yang harus dimiliki oleh seorang guru. Dalam kompetensi ini seorang guru harus mampu meliki

1) Bersikap inklusif, bertindak objektif serta tidak diskriminatif, karena pertimbangan jenis kelamin, agama, ras, kondisi fisik, latar belakang keluarga dan status sosial ekonomi.

2) Berkomunikasi secara efektif, simpatik, dan santun dengan sesama pendidik, tenaga kependidikan, orang tua dan masyarakat.

3) Beradaptasi di tempat bertugas diseluruh wilayah republik Indonesia.

4) Berkomunikasi dengan komunitas profesi sendiri dan profesi lain secara lisan dan tulisan atau bentuk lain. (Wahyudi, $2012: 25$ )

Kompetensi sosial dalam kegiatan belajar ini berkaitan erat dengan kemampuan guru dalam berkomunikasi dengan masyarakat di sekitar sekolah dan masyarakat tempat guru tinggal sehingga peranan dan cara guru berkomunikasi di masyarakat diharapkan memiliki karakteristik tersendiri yang sedikit banyak berbeda dengan orang lain yang bukan guru. Misi yang diemban guru adalah misi kemanusiaan. Mengajar dan mendidik adalah tugas kemanusiaan manusia. Guru harus mempunyai kompetensi sosial karena guru adalah penceramah jaman.

Menurut Djam’an Satori, (2007 : 43) kompetensi sosial adalah sebagai berikut.

1) Terampil berkomunikasi dengan peserta didik dan orang tua peserta didik.

2) Bersikap simpatik.

3) Dapat bekerja sama dengan Dewan Pendidikan/Komite Sekolah.

4) Pandai bergaul dengan kawan sekerja dan mitra pendidikan.

5) Memahami dunia sekitarnya (lingkungan).

Dalam UU guru dan dosen, kompetensi sosial sebagaimana yang dimaksud pada ayat 2 merupakan kemampuan guru sebagai bagian dari masyarakat yang sekurangkurangnya meliputi kompetensi untuk:

1) Bekomunikasi lisan, tulis, dan/atau isyarat secara santun,

2) Menggunakan teknologi komunikasi dan informasi secara fungsional,

3) Bergaul secara efektif dengan peserta didik, sesama pendidik, tenaga kependidikan, pemimpin satuan pendidikan, orang tua atau wali peserta didik, 
4) Bergaul secara santun dengan masyarakat sekitar dengan mengindahkan norma serta sistem nlai yang berlaku, dan

5) Menerapkan perinsip persaudaraan sejati dan semangat kebersamaan (Undangundang guru dan dosen, $2011: 66-67)$

Kompetensi sosial merupakan kemampuan guru untuk menyesuaikan diri kepada tuntutan kerja di lingkungan sekitar pada waktu membawakan tugasnya sebagai guru. Peran yang dibawa guru dalam masyarakat berbeda dengan profesi lain. Oleh karena itu, perhatian yang diberikan masyarakat terhadap guru pun berbeda dan ada kekhususan terutama adanya tuntutan untuk menjadi pelopor pembangunan di daerah tempat guru tinggal.

Jadi, sebagai guru yang baik dan profesional itu tidak hanya mampu berkomunikasi dengan lingkungan kelas dan sekolah tetapi juga bisa berhubungan baik dengan masyarakat sekitar, bisa menjadi sumber ilmu bagi masyarakat dan memberikan kontribusi yang positif.

\section{Kompetensi Profesional}

Guru profesional adalah guru yang memiliki kompetensi yang dipersyaratkan untuk melakukan tugas pendidikan dan pengajaran. Kompetensi di sini meliputi pengetahuan, sikap, dan keterampilan profesional, baik yang bersifat pribadi, sosial, maupun akademis. Kompetensi profesional merupakan salah satu kemampuan dasar yang harus dimiliki seseorang guru. Dalam Peraturan Pemerintah No 19 tahun 2005, pada pasal 28 ayat 3 yang dimaksud dengan kompetensi profesional adalah kemampuan penguasaan materi pembelajaran secara luas dan mendalam yang memungkinkannya membimbing peserta didik memenuhi standar kompetensi yang ditetapkan dalam Standar Nasional Pendidikan.

Merupakan kemampuan dalam penguasaan materi pembelajaran secara luas dan mendalam yang memungkinkannya membimbing peserta didik memenuhi standar kompetensi. Kompetensi professional guru merupakan kompetensi yang menggambarkan kemampuan khusus yang sadar dan terarah kepada tujuan-tujuan tertentu.

Adapun dalam kompetensi ini seorang guru hendaknya mampu untuk:

1) Menguasai materi, struktur, konsep dan pola pikir keilmuan yang mendukung mata pelajaran yang ditempuh.

2) Menguasai standar kompetensi dan kompetensi dasar mata pelejaran/bidang pengembangan yang ditempuh. 
3) Mengembangkan materi pembelajaran yang diampu secara kreatif.

4) Mengembangkan keprofesionalan serta berkelanjutan dengan melakuan tindakan reflektif.

5) Memanfaatkan teknologi informasi dan komunikasi untuk berkomunikasi dan mengembangkan diri. (Wahyudi, 2012 : 23-24).

Dengan kata lain pengertian guru profesional adalah orang yang punya kemampuan dan keahlian khusus dalam bidang keguruan sehingga ia mampu melakukan tugas dan fungsinya sebagai guru. Guru profesional adalah orang yang terdidik dan terlatih serta punya pengalaman bidang keguruan. Seorang guru profesional dituntut dengan sejumlah persyaratan minimal antara lain; memiliki kualifikasi pendidikan profesi yang memadai, memiliki kompetensi kemampuan berkomunikasi dengan siswanya, mempunyai jiwa kreatif dan produktif, mempunyai etos kerja dan komitmen tinggi terhadap profesinya dan selalu melakukan pengembangan diri secara terus-menerus (continous improvement) melalui organisasi profesi, buku, seminar, dan semacamnya.

Secara umum kompetensi profesional dapat diidentifikasi tentang ruang lingkup kompetensi profesional guru adalah sebagai berikut:

1) Kemampuan penguasaan materi/bahan bidang studi. Penguasaaan ini menjadi landasan pokok untuk keterampilan mengajar.

2) Kemampuan mengelola program pembelajaran yang mencakup merumuskan standar kompetensi dan kompetensi dasar, merumuskan silabus, tujuan pembelajaran, kemampuan menggunakan metode/model mengajar, kemampuan menyusun langkahlangkah kegiatan pembelajaran, kemampuan mengenal potensi (entry behavior) peserta didik, serta kemampuan merencanakan dan melaksanakan pengajaran redmedial.

3) Kemampuan mengelola kelas. Kemampuan ini antara lain adalah; mengatur tata ruang kelas dan menciptakan iklim belajar mengajar yang kondusif.

4) Kemampuan mengelola dan penggunaan media serta sumber belajar. Kemampuan ini pada dasarnya merupakan kemampuan menciptakan kondisi belajar yang merangsang agar proses belajar mengajar dapat berlangsung secara efektif dan efisien.

5) Kemampuan penguasaan tentang landasan kependidikan. Kemampuan menguasai landasan-landasan kependidikan. 
6) Kemampuan menilai prestasi belajar peserta didik yaitu kemampuan mengukur perubahan tingkah laku siswa dan kemampuan mengukur kemahiran dirinya dalam mengajar dan dalam membuat program.

7) Kemampuan memahami prinsip-prinsip pengelolaan lembaga dan program pendidikan di sekolah.

8) Kemampuan/terampil memberikan bantuan dan bimbingan kepada peserta didik.

9) Kemampuan memiliki wawasan tentang penelitian pendidikan.

10) Kemampuan memahami karakteristik peserta didik. Guru dituntut memiliki pemahaman yang lebih mendalam tentang ciri-ciri dan perkembangan peserta didik, lalu menyesuaikan bahan yang akan diajarkan sesuai dengan karakteristik peserta didik.

11) Kemampuan menyelenggarakan administrasi sekolah.

12) Kemampuan memiliki wawasan tentang inovasi pendidikan.

13) Kemampuan/berani mengambil keputusan.

14) Kemampuan memahami kurikulum dan perkembangannya.

15) Kemampuan bekerja berencana dan terprogram.

16) Kemampuan menggunakan waktu secara tepat.(Mulyasa, 2007: 135 -138)

Dalam UU guru dan dosen, kompetensi profesional sebagaimana yang dimaksud pada ayat 2 merupakan kemampuan guru dalam menguasai pengetahuan bidang ilmu pengetahuan, teknologi, dan/atau seni dan budaya yang diampunya yang sekurangkurangnya meliputi penguasaan:

1) Materi pelajaran secara luas dan mendalam sesuai standar isi program satuan pendidikan, mata pelajaran, dan/atau kelompok mata pelajaran yang akan diampu, dan

2) Konsep dan metode disiplin keilmuan, teknologi, atau seni yang relevan, yang secara konseptual menaungi atau koheren dengan program satuan pendidikan, mata pelajaran, dan/atau kelompok mata pelajaran yang akan diampu. (Undang-Undang Guru dan Dosen, $2011: 67$ )

Jadi, dari uraian ruang lingkup diatas dapat disimpulkan bahwa kompetensi profesional guru adalah sejumlah kompetensi yang berhubungan dengan profesi yang menuntut berbagai keahlian di bidang pendidikan atau keguruan. Kompetensi profesional merupakan kemampuan dasar guru dalam pengetahuan tentang belajar dan tingkah laku manusia, bidang studi yang dibinanya, sikap yang tepat tentang lingkungan PBM dan mempunyai keterampilan dalam teknik mengajar. 


\section{Kesimpulan}

Kompetensi merupakan kemampuan yang harus dimiliki seseorang baik pengetahuan, keterampilan, maupun nilai dan sikap untuk melakukan suatu pekerjaan yang tidak dapat dilakukan oleh orang lain yang tidak memiliki kemampuan tersebut. Seorang guru yang profesional seharusnya memiliki 4 kompetensi yaitupertama, kompetensi pedagogikyaitu kemampuan seorang guru dalam mengelola proses pembelajaran peserta didik.Kedua, Kompetensi kepribadian yaitu penguasaan kepribadian yang mantap, stabil, dewasa, arif dan berwibawa, menjadi teladan bagi peserta didik dan berakhlak mulia.Ketiga Kompetensi sosial yaitu kemampuan berkomunikasi secara efektif dengan peserta didik, sesama pendidik/tenaga kependidikan lain, orang tua/wali peserta didik dan masyarakat sekitar.Ke empat Kompetensi profesional yaitu kemampuan dalam penguasaan materi pembelajaran secara luas dan mendalam yang memungkinkannya membimbing peserta didik memenuhi standar kompetensi. Kompetensi profesional guru merupakan kompetensi yang menggambarkan kemampuan khusus yang sadar dan terarah kepada tujuan-tujuan tertentu.

\section{DAFTAR PUSTAKA}

Arsyad, dan Sulfemi, Wahyu Bagja. (2014). Minat Siswa Tentang Keadministrasian dengan Hasil Belajar Administrasi Perkantoran. Edutecno. 9 (2), 40-50.

Badar, Dadan Samsul dan Sulfemi, Wahyu Bagja. (2014). Pengaruh Rasa Percaya Diri dan Motivasi Berprestasi Terhadap Kinerja di Kecamatan Ciampea Kabupaten Bogor. Edutecno. 10 (1), 1-10,

Fajartriani, Tia dan Sulfemi, Wahyu Bagja. (2014). Pengaruh Motivasi Kerja Guru dan Iklim Organisasi Terhadap Kinerja Guru SMA Negeri di Kecamatan Cigudeg. Edutecno. 8 (1), 17-26

Uno, Hamzah. Profesi Kependidikan: Problema, Solusi, dan Reformasi Pendidikan di Indonesia. Jakarta: Bumi Aksara. 2008

Hawi, Akmal. (2010). Kompetensi Guru PAI. Palembang: Rafah Press.

Mulyasa, E. (2007). Standar Kompetensi dan Sertifikasi Guru. Bandung: Remaja Rosdakarya.

Muslich, Masnur. (2007) KTSP Pembelajaran Berbasis Kompetensi dan Konteksrual: Panduan Bagi Guru, Kepala Sekolah, dan Pengawas Sekolah. Jakarta: Bumi Aksara.

Roqib, Moh. dan Nurfuadi. (2009). Kepribadian Guru: Upaya Mengembangkan Kepribadian Guru yang Sehat di Masa Depan. Yogyakarta: Grafindo Litera Media. 
Satori, Djam'an dkk. (2007). Profesi Keguruan. Jakarta: Universitas Terbuka. Sultoni, Wahyu Bagja, (2007). Ilmu Sosial Dasar. Bogor : STKIP Muhamadiyah.

Sulfemi, Wahyu Bagja., (2007). Ilmu Sosial Dasar. Bogor : STKIP Muhamadiyah Bogor.

Sulfemi, Wahyu Bagja. (2013). Pengaruh Persepsi Siswa atas Kemampuan Pedagogik Guru dan Motivasi Belajar Siswa Terhadap Prestasi Belajar Ilmu Pengetahuan Sosial Siswa (Survei di SMK Swasta Kabupaten Bogor). Edutecno. 7 (2), 17-26.

Sulfemi, Wahyu Bagja. (2014). Pengaruh Motivasi dan Lingkungan Sekolah Terhadap Prestasi Belajar Sejarah Di SMA Negeri Leuwilang Kabupaten Bogor. Fascho : Kajian Pendidikan dan Sosial Kemasyarakatan 9 (2), 42-52.

Undang-undang Guru dan Dosen, ( 2011.) Bandung: FOKUSMEDIA..

Wahyudi, Imam. (2012). Panduan Lengkap Uji Sertifikasi Guru. jakarta: PT Prestasi Pustakatya.. 